\title{
Synthesis of sulphated proteoglycans by rheumatoid and normal synovial tissue in culture
}

\author{
JOANNE M. MARSH, ${ }^{1}$ O. W. WIEBKIN, SALLY GALE, \\ H. MUIR, AND R. N. MAINI
}

From the Mathilda and Terence Kennedy Institute of Rheumatology, London, England and ${ }^{1}$ Dalhousie. University, Halifax, Nova Scotia, Canada

SUMMARY Synthesis of sulphated proteoglycans by cell lines derived from explants of 7 rheumatoid and 9 normal specimens of synovial tissue, as well as by 7 lines of skin fibroblasts from non-rheu- $\infty$ matoid patients, was examined. Cells of all 3 types were cultured as monolayers. They were then $\stackrel{N}{-}$ disaggregated and their capacity to synthesise proteoglycan estimated in cell suspensions by the incorporation of $\left.{ }^{355} \mathrm{~S}\right]$-sulphate into CPC-precipitable material during 2 hours of incubation. Cello suspensions incorporated somewhat more $\left[{ }^{35} \mathrm{~S}\right]$-sulphate than corresponding duplicate monolayers. $\rightarrow$ Synovial cells from rheumatoid patients incorporated 2 to 3 times as much $\left[{ }^{35} \mathrm{~S}\right]$-sulphate as synovial cells from normals. Skin fibroblasts, however, incorporated less $\left.{ }^{35} \mathrm{~S}\right]$-sulphate than rheumatoid or normal synovial cells up to the fifth passage. Thereafter their incorporation gradually increased to $\vec{\theta}$ overtake that of synovial cells. About one-half to one-third of the total $\left.{ }^{35} \mathrm{~S}\right]$-sulphate labelled. 0 material was closely associated with cells from synovial tissues and fibroblasts respectively.

Urine, plasma, and synovial fluid from patients with rheumatoid arthritis have been shown to contain increased levels of chondroitin sulphate when compared with similar fluid obtained from non-rheumatoid sources (Badin et al., 1955; Di Ferrante, 1957; Barker et al., 1966).

Since the supernatants of normal synovial cell cultures appeared to contain little or no sulphated proteoglycans when examined by either critical electrolyte concentration methods or moving boundary electrophoresis (Kling et al., 1955; Fraser et al., 1965; Baxter et al., 1973), it was generally believed that the elevated levels of sulphated proteoglycans in the body fluids of rheumatoid patients did not arise from the synovium but from the breakdown of the matrix of articular cartilage (Badin et al., 1955).

However, with the use of $\left[{ }^{35} \mathrm{~S}\right]$ sulphate the present

Accepted for publication 11 May 1978

Correspondence to Dr Joanne M. Marsh, Victoria General Hospital, Halifax, Nova Scotia, Canada B3H 2Y9 studies have shown that both normal and rheumatoid synovial cells maintained in long term culture $\mathbb{Q}$ synthesised proteoglycans. There were significant $\underset{7}{\overrightarrow{2}}$ effects of passage and age of the cultures on pro-윽 teoglycan synthesis.

\section{Materials and methods}

CELL CULTURES

Cell cultures were derived by means of techniques involving explant culture (Marsh et al., 1978) from 7 rheumatoid and 9 normal human synovial tissue $₹$ specimens (see Table 1 for clinical features). Seven을 normal synovial specimens were obtained at menis- $\rightarrow$ cectomy and 2 were obtained at necropsy. Allo rheumatoid synovial tissue was obtained at surgical operations. For comparative purposes 7 lines of skin - ? fibroblasts were cultured from skin excised at the $N$ time of abdominal surgery from non rheumatoid patients.

Table 1 Clinical features of donors of synovial tissue

\begin{tabular}{|c|c|c|c|c|c|c|c|c|c|c|c|}
\hline \multirow[t]{2}{*}{ Tissue } & \multirow[t]{2}{*}{ Number } & \multicolumn{2}{|c|}{ Age (years) } & \multicolumn{2}{|c|}{$\operatorname{Sex}$} & \multirow{2}{*}{$\begin{array}{l}\text { Source } \\
\text { Knee }\end{array}$} & \multirow[b]{2}{*}{ Other } & \multicolumn{2}{|c|}{$A R A$ category } & \multicolumn{2}{|l|}{$\boldsymbol{R} F$} \\
\hline & & Mean & Range & $M$ & $F$ & & & Class. & Def. & $\geq 1: 16$ & 0 \\
\hline Rheumatoid synovium & 7 & 62 & $54-68$ & 1 & 6 & 5 & 2 & 5 & 2 & 6 & 1 \\
\hline Normal synovium & 9 & 38 & $19-64$ & 4 & 5 & 9 & $\mathbf{0}$ & - & - & 0 & 9 \\
\hline Skin fibroblasts & 7 & 47 & $1-66$ & 5 & 2 & 0 & 7 & - & - & 0 & 7 \\
\hline
\end{tabular}


The synovial tissue was grossly dissected to remove as much subintimal connective tissue as possible and then cut into small pieces, $1-2 \mathrm{~mm}^{3}$. The small pieces of tissue (explants) were placed in Petri dishes containing nutrient medium (Dulbecco's modification of Eagle's minimum essential medium, Flow Laboratories Scotland) supplemented with ascorbic acid $(50 \mu \mathrm{g} / \mathrm{ml})$, L-glutamine $(1 \mathrm{mg} / \mathrm{ml})$, penicillin $(50 \mu \mathrm{g} / \mathrm{ml})$, streptomycin $(50 \mu \mathrm{g} / \mathrm{ml})$, and $30 \%$ heat inactivated fetal calf serum. The concentration of the fetal calf serum was gradually reduced to $20 \%$ when a confluent monolayer of cells had developed and were ready to be subcultured. Incubation was carried out at $37^{\circ} \mathrm{C}$ in an atmosphere of $10 \% \mathrm{CO}_{2}$ and room air.

When sufficient numbers of cells had grown out of the explants to form a monolayer, the cell strains were subcultured as follows: cells were disaggregated by incubating at $37^{\circ} \mathrm{C}$ with $0.125 \%$ crystaline trypsin (type I, Sigma Chemical Co., Kingston, Surrey, UK) in $0.004 \mathrm{M}$ EDTA for 30 seconds. The trypsin-EDTA solution was removed and the cells incubated for another 30 seconds. The cells were then suspended in fresh medium containing $20 \%$ fetal calf serum. This cell suspension was subcultured directly or used in the $\left[{ }^{35} \mathrm{~S}\right]$-sulphate incorporation studies, after an aliquot was enumerated in a haemocytometer or electronic particle counter (Coulter Counter, Model DN, Coulter Electronics). Each such disaggregation and subculturing procedure was regarded as a passage. Between 10 and 14 days after the first passage, cells had again grown in a confluent monolayer and were then termed 'cell lines.' The cultures studied were grouped into those of the first to the fifth passage inclusive, and those of later passages as previous investigations (Marsh et al., 1978) have shown that cell cultures alter significantly by the sixth passage.

[ ${ }^{35}$ S]-SULPHATE INCORPORATION TECHNIQUES The incorporation of $\left[{ }^{35} \mathrm{~S}\right]$-sulphate into cetylpyridinium chloride (CPC)-precipitable macromolecules by skin fibroblasts, by normal synovial cells, and by rheumatoid synovial cells was determined under 2 separate conditions: $(a)$ in short-term suspension cultures, and $(b)$ in monolayer cultures, by a modification of the technique described by Wiebkin and Muir (1973).

(a) Short-term suspension cultures. Suspension cultures of cells were prepared by disaggregating cells from fully confluent monolater cultures, as described above. The disaggregated cells were placed in $5 \mathrm{ml}$ of fresh medium containing $20 \%$ fetal calf serum and an aliquot taken from enumeration in the Coulter counter. After centrifuging the cell suspension at $80 \mathrm{~g}$ for 10 minutes the medium was removed and replaced by $1.5 \mathrm{ml}$ of Tyrode's balanced salt solution. The cells were washed twice in Tyrode's solution and then resuspended in $1 \mathrm{ml}$ of Tyrode's solution containing $10 \mu \mathrm{Ci}$ of carrier-free $\left[{ }^{35} \mathrm{~S}\right]$-sulphate (Radiochemical Centre, Amersham, Bucks, UK) and incubated for 2 hours at $37^{\circ} \mathrm{C}$ in $5 \% \mathrm{CO}_{2}$ and air. After incubation the cells were centrifuged free of their media, at $500 \mathrm{~g}$ for 10 minutes, and washed twice in Tyrode's solution containing $0.05 \mathrm{M} \mathrm{Na} \mathrm{NO}_{4}$. Washings and media were pooled and termed 'supernatants'. To both cells and supernatants $5 \%$ CPC was added separately to a final concentration of $1 \%$. The mixtures were stirred vigorously with kieselguhr (Hopkins and Williams, Chadwell Heath, Essex, UK), incubated overnight at $20^{\circ} \mathrm{C}$, and then stirred again and centrifuged at $500 \mathrm{~g}$ for 10 minutes. The pellets were washed free of non-precipitated sulphate with $1 \%$ CPC by resuspending and centrifuging 3 times. Pellets were incubated at $56^{\circ} \mathrm{C}$ for 30 minutes in 4 volumes of $1 \mathrm{M}$ hyamine-hydroxide and radioactivity measured. Radioactivity was expressed as $\mathrm{dpm} / 10^{4}$ cells for both the cell and supernatant samples. The total incorporation of $\left[{ }^{35} \mathrm{~S}\right]$-sulphate into CPC-precipitable macromolecules was calculated as follows:

Total $\left[{ }^{35} \mathrm{~S}\right]$-sulphate incorporation $/ 10^{4}$ cells $=$ $\mathrm{dpm}$ cell pellet $+\mathrm{dpm}$ supernatant

$$
10^{4} \text { cells }
$$

A minimum of 3 determinations were made on each cell line at each passage studied. A retention index (R) was also calculated for each culture studied. This index, describing the proportion of cell-associated macromolecules, was expressed as follows:

$$
\mathrm{R}=\frac{\left[{ }^{35} \mathrm{~S}\right] \text {-sulphate in cell pellet }}{\text { Total }\left[{ }^{35} \mathrm{~S}\right] \text {-sulphate incorporated }} \times 100
$$

(b) Monolayer cultures. Duplicate monolayer cultures of cells originally derived from skin, normal synovium, and rheumatoid synovium were prepared. When the cultures were fully confluent, 1 culture of each duplicate was taken into suspension, and the incorporation of $\left.{ }^{35} \mathrm{~S}\right]$-sulphate into CPC-precipitable macromolecules was determined by the method described for the short-term suspension culture. The other duplicate culture was retained in the monolayer state and washed free of medium with 3 washings of Tyrode's solution. Such monolayer cultures were incubated at $37^{\circ} \mathrm{C}$ in $5 \% \mathrm{CO}_{2}$ and air in $5 \mathrm{ml}$ of Tyrode's solution containing $15 \mu \mathrm{Ci}$ of $\left[{ }^{35} \mathrm{~S}\right]$-sulphate for 2 hours. The monolayer cultures were then brought into suspension by means of a 'rubber policeman' and then transferred to testtubes. The entire contents of the culture were centrifuged and media removed and saved as 'supernatant' sample. Cells were then washed twice 
in Tyrode's solution containing $0.05 \mathrm{M} \mathrm{Na} \mathrm{Na}_{4}$. These washings and media were pooled. CPCprecipitation and measurement of radioactivity was performed on both cells and supernatants, as described above. Duplicate suspension cultures (as described above) were used for both incorporation of $\left[{ }^{35} \mathrm{~S}\right]-$ sulphate and for enumeration of cell numbers. The number of cells per monolayer culture was determined by extrapolation from duplicate suspension culture data.

\section{Results}

SHORT-TERM SUSPENSION CULTURES

The total incorporation per $10^{4}$ cells of $\left[{ }^{35} \mathrm{~S}\right]-$ sulphate into CPC-precipitable macromolecules by short-term suspension cultures of skin fibroblasts and normal and rheumatoid synovial cells were grouped into those from the first to the fifth passage inclusive, and those of later passages (Fig. 1). In the

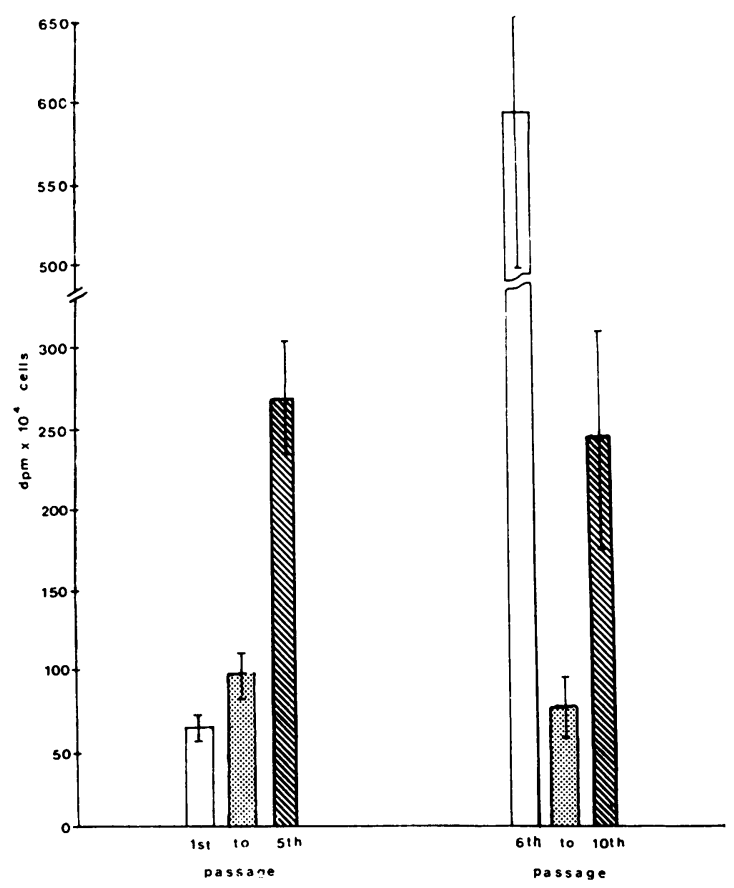

Fig. 1 The incorporation of $\left[{ }^{35} \mathrm{~S}\right]$-sulphate into CPCprecipitable macromolecules by suspension cultures. Bars show mean $\pm 1 S E$ for each group. $\square=$ Skin fibroblast cultures. Passage 1-5 = mean of 40 cell cultures; passage $6-10=$ mean of 44 cell cultures. Normal synovial tissue cultures. Passage $1-5=$ mean of 51 cell cultures; passage $6-10=$ mean of 11 cell cultures $\mathbb{N}=$ Rheumatoid synovial tissue cultures. Passage 1-5 mean of 23 cell cultures. passage 6-10=mean of 11 cell cultures. analysis of the data all differences between mean? values were subjected to Cochran and Cox's modification of Student's $t$ test.

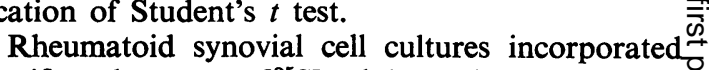
significantly more $\left[{ }^{35} \mathrm{~S}\right]$-sulphate into CPC-pre-c cipitable material than did normal synovial cell $\overline{\frac{\sigma}{\omega}}$ cultures $(P<0 \cdot 01)$. On the other hand the incor- $\overparen{\nabla}$ poration by skin fibroblasts was significantly less $\bigcirc$ than that of normal synovial cells during the first 5 passages $(P<0.05)$. After the fifth passage, how- $\overrightarrow{0}$ ever, the incorporation by skin fibroblasts increased significantly $(P<0.01)$, and this incorporation was significantly greater than that of normal synovial cells $(P<0.01)$ or rheumatoid synovial cells $\left(P<\frac{0}{0}\right.$ $0 \cdot 05$ ). However, rheumatoid cultures continued to $\omega_{\infty}$ incorporate significantly more $\left[{ }^{35} \mathrm{~S}\right]$-sulphate $(\mathrm{P}<\dot{\mathrm{T}}$ $0.05)$ than did normal synovial cultures during these $\vec{\sigma}$ later passages.

SULPHATE RETENTION INDEX

The proportion of the $\left[{ }^{35} \mathrm{~S}\right]$-sulphate associated with normal or rheumatoid synovial cells was $40-50 \%$. of the total incorporation (Fig. 2). There was now

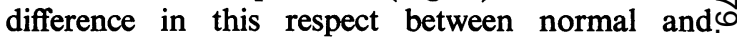
rheumatoid cells. With skin fibroblasts, however, about $30 \%$ of the total incorporation was associated with the cells, and the difference between synovial cells and skin fibroblasts was statistically significant $(P<0.01)$ and was maintained right through to the $\underset{\propto}{\mathbb{Q}}$ tenth passage $(P<0.05)$.

\section{MONOLAYER CULTURES}

Fig. 3 compares the incorporation of $\left.{ }^{[35} \mathrm{S}\right]$-sulphate into CPC-precipitable material by the 3 types of cells at the fourth passage in monolayer and shortterm suspension cultures. In all experiments sus-윽 pension cultures incorporated somewhat more $\left.{ }^{35} \mathrm{~S}\right]$-sulphate than the corresponding monolayero cultures.

\section{Discussion}

The incorporation in vitro of $\left[{ }^{35} \mathrm{~S}\right]$ sulphate inton CPC-precipitable material reflects the active syn-thesis of proteoglycans (Gregory and Robbins,1960). N During the CPC-precipitation the effective electro- $\mathbb{\omega}$ lyte concentration in the supernatants or cell samples? was no greater than $0.14 \mathrm{M}$ or $0.029 \mathrm{M}$ respectivelyo and hence was well below the critical electrolyte concentration above which sulphated glycosamino-? glycans are not precipitated (Scott, 1955).

To maximise labelling the cells were incubated in Tyrode's balanced salt solution, which contains no sulphate, and cells were used in suspension as the $\underset{\varrho}{\mathbb{Q}}$ incorporation of $\left[{ }^{35} \mathrm{~S}\right]$-sulphate was greater than ing monolayers. Total labelled material precipitable by 


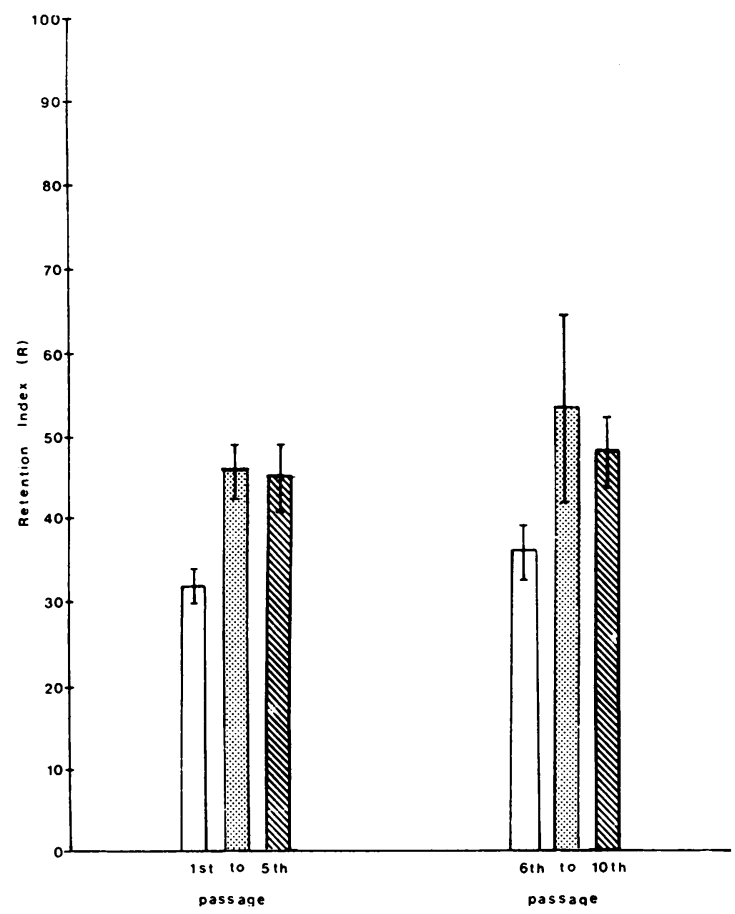

Fig. 2 The cell retention indices $\left(100 \times\left[{ }^{35} \mathrm{~S}\right]-\right.$ sulphate incorporation in cell pellet/total $\left[{ }^{35} \mathrm{~S}\right]-$ sulphate incorporation) for sulphated macromolecules synthesised by suspension cultures. Bars show mean $: 1 S E$ for each group. $\square==$ Skin fibroblast cultures. Passage 1-5 =: mean of 40 cell cultures; passage $6-10=$ mean of 44 cell cultures. $=$ Normal synovial tissue cultures. Passage 1-5 = Mean of 51 cell cultures; passage 6-10mean of 11 cell cultures. tissue cultures. Passage 1-5 mean of 23 cell cultures; passage $6-10=$ mean of 11 cell cultures.

CPC in both cells and supernatant was estimated and not that in the supernatants alone. About $40-50 \%$ of the labelled material was associated with synovial cells (Fig. 2). This has also been observed with chondrocyte cultures (Srivistava et al., 1974; Wiebkin and Muir, 1977).

Stidworthy et al. (1973) has reported that glycosaminoglycan synthesis decreased with age both in vitro and in vivo and that the relative amount of nonsulphated to sulphated glycosaminoglycans also increased. The donors of normal synovial tissue were not matched for age, but the individual cell lines did not show any positive correlation between donor age and levels of sulphated proteoglycan synthesis (Fig. 4).

Changes in morphology of synovial cells with each successive passage in culture have recently been

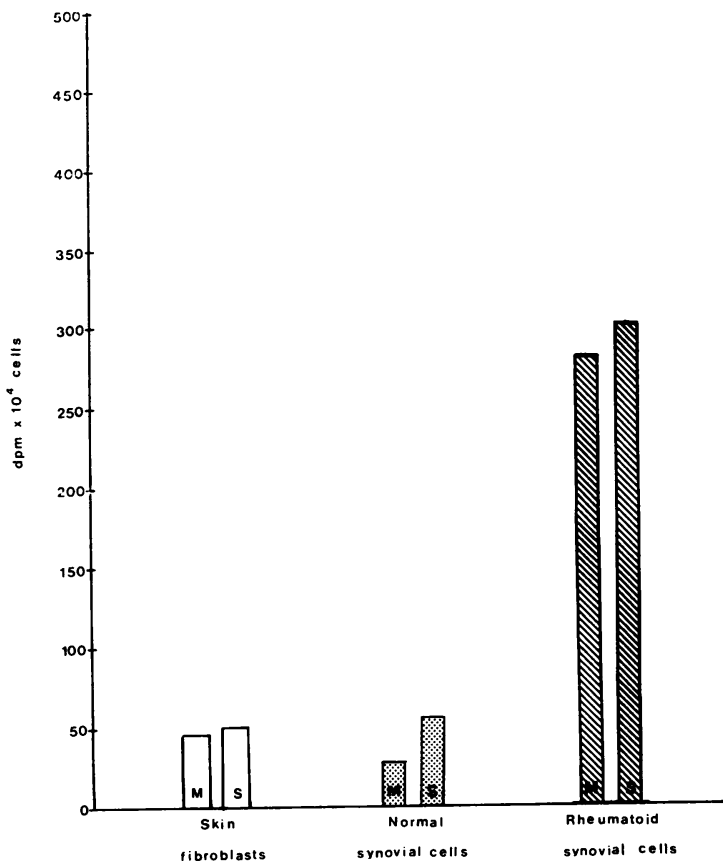

Fig. 3 The incorporation of $\left.{ }^{35} \mathrm{~S}\right]-$ sulphate into $C P C$ precipitable macromolecules by monolayers and suspension at the fourth passage. Mean of duplicate experiments on individual cell lines are shown. $M=$ monolayer culture, $S=$ suspension culture.

demonstrated. By the sixth passage cells were markedly uniform in size and buoyant density (Marsh et al., 1978), and it is emphasised that in comparative studies cultures should be matched for passage number. When this was done, it was found that up to the fifth passage skin fibroblasts synthesised less proteoglycan than synovial cells and that rheumatoid synovial cells synthesised 2 to 3 times more than normal synovial cells. Although the standard error differences of the means was large, they were nevertheless statistically significant.

The results suggest that the rheumatoid synovial cells may have undergone a metabolic change that was not reversed in culture after many passages. It also appears that, when comparisons were being made, cells cultured for the same length of time and number of passages should be used. As polyanions bind Clq component of complement (Agnello et al., 1969), the production of increased amounts of sulphated polyanion by rheumatoid synovial tissue in vivo might activate complement locally and so potentiate inflammation in the joint.

The authors thank the surgical staffs of the West Lcndon Hospital, New Charing Cross Hospital, and St Stephen's 


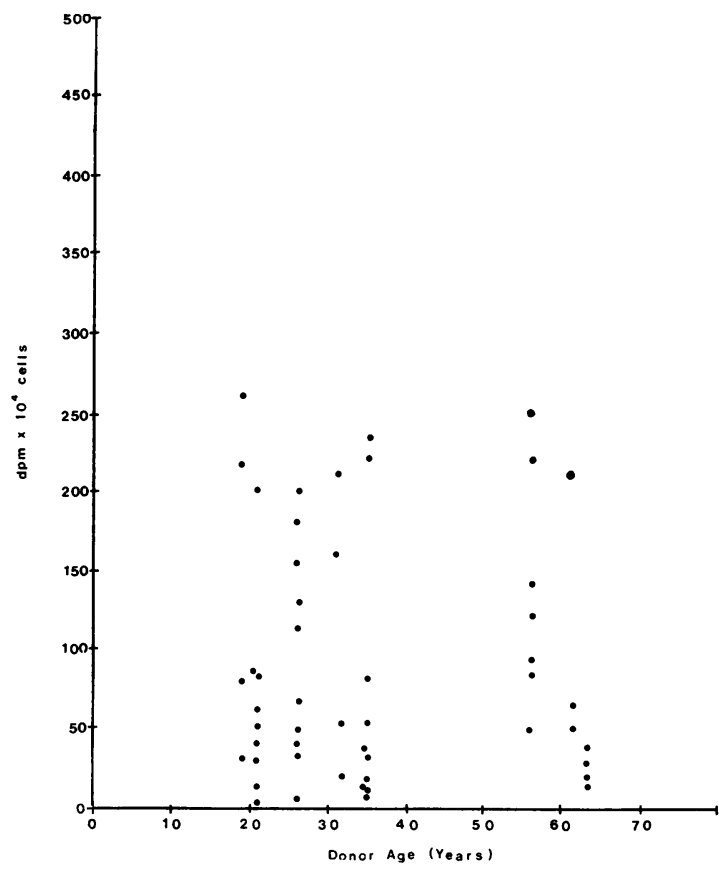

Fig. 4 The incorporation of $\left[{ }^{35} \mathrm{~S}\right]-$ sulphate by 51 normal synovial cell cultures, passage 1-5 (derived from 9 donors) versus age of donors $(r=+0.035)$.

Hospital for their co-operation in providing the surgical specimens. This work was supported in part by a Canadian Arthritis and Rheumatism Society fellowship (for M.J.M.).

\section{References}

Agnello, V., Carr, R. I., Koffier, D., and Kunkel, H. G. (1969). Gel diffusion reactions of C1q with aggregated globulin, DNA and other anionic substances. Federation Proceedings, 28, 2447.
Badin, J., Schubert, M., and Vouras, M. (1955). Plasma polysaccharide fraction containing uronic acid, in normates? subjects and in patients with rheumatoid arthritis. Journal of Clinical Investigation, 34, 1317-1323.

Barker, S. A., Hawkins, C. F., and Hewins, M. (1966) Mucopolysaccharides in synovial fluid: detection of chondroitin sulphate. Annals of the Rheumatic Diseases, 25, 209-213.

Baxter, E., Fraser, J. R. E., and Harris, G. S. (1973) $\mathbb{D}$ Fractionation and recovery of secretions of synovial cells synthesised in cu'ture with radioactive precursors. Annalses of the Rheumatic Diseases, 32, 35-40.

Di Ferrante, N. (1957). Urinary excretion of acid muco-polysaccharides by patients with rheumatoid arthritis. Journal of Clinical Investigation, 36, 1516-1520.

Fraser, J. R. E., and McCall, J. F. (1965). Culture of syno-ఎे vial cells in vitro. Notes on isolation and propagation. $\overline{\mathrm{C}}$ Annals of the Rheumatic Diseases, 24, 351-359.

Gregory, J. D., and Robbins, P. W. (1960). Metabolism of 9 sulfur compounds. Annual Review of Biochemistry, 29, 347-364.

Kling, D. H., Levine, M. G., and Wise, S. (1955). Muco-ช polysaccharides in tissue culture of human and mam-을 malian synovial membrane. Proceedings of the Society forExperimental Biology and Medicine, 89, 261-263.

Marsh, J. M., Maini, R. N., Wiebkin, O. W., and Dumonde, D. C. (1978). Rheumatoid and normal synovial tissue in long-term culture: Evidence of cell heterogeneity and an $\vec{c}$ approach to quantitation of populations and the effects of passage. Journal of Rheumatology, 5, 148-161.

Scott, J. E. (1955). The solubility of cetylpyridinium complexes of biological polyanions in solutions of salts. Biochimica et Biophysica Acta, 18, 428-429.

Srivistava, V. M. L., Malemud, C. J., and Sokoloff, L.O (1974). Chondroid expression by lapine articular chondro-o

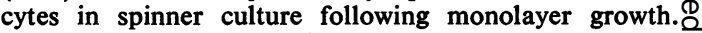
Connective Tissue Research, 2, 127-136.

Stidworthy, G. H., Kurtz, M. J., Burrans, M. L., and Gill, P. J. (1973). Control of synthesis of collagen and glycosaminoglycan by fibroblasts of different clonal age. In Vitro, 8, 429.

Wiebkin, O. W., and Muir, H. (1973). The inhibition of sulphate incorporation in isolated adult chondrocytes by hyaluronic acid. FEBS Letters, 37, 42-46.

Wiebkin, O. W., and Muir, H. (1977). Synthesis of pro-teoglycans by suspension and monolayer cultures of adult. chondrocytes and de novo cartilage nodules-the effect of hyaluronic acid. Journal of Cell Science, 27, 199-211. 